\title{
Precipitous decline and conservation of Slackwater Darter (Etheostoma boschungi) in tributaries of the Tennessee River, Tennessee and Alabama
}

\author{
Carol E. Johnston · Andrew R. Henderson • Wendi W. Hartup
}

Received: 14 June 2013/Accepted: 23 September 2013/Published online: 2 October 2013

(C) The Author(s) 2013. This article is published with open access at Springerlink.com

\begin{abstract}
Etheostoma boschungi (Slackwater Darter) is a migratory fish species endemic to tributaries of the Tennessee River. Although the distribution of this species was historically disjunct and limited, current data suggest that the species is suffering a decline in both distribution and abundance, resulting in critically low population levels. Data collected over a 10-year period demonstrate an approximate $45 \%$ distributional decline relative a previous survey. In addition, numbers of individuals collected at breeding sites has also declined during this time period. Detectability for sites with repeated sampling effort suggest that even where the species persists, it may be in numbers too low for detection with just one effort. Factors affecting persistence of Slackwater Darters may include passage barriers, such as culverts and loss of connectivity to flooded breeding sites due to channel incision, but data on the effects of these environmental factors are largely lacking.
\end{abstract}

Keywords Percidae $\cdot$ Fish passage $\cdot$ Migratory $\cdot$ Ozarka

C. E. Johnston ( $₫)$ · A. R. Henderson · W. W. Hartup

Fish Biodiversity Lab, Department of Fisheries, Auburn University, Auburn, AL 36849, USA e-mail: Johnsc5@auburn.edu

A. R. Henderson

e-mail: ahenderson@tva.gov

W. W. Hartup

e-mail: wendi_hartup@ncsu.edu

Present Address:

A. R. Henderson

Tennessee Valley Authority, 400 West Summitt Hill Drive, Knoxville, TN 37902, USA

Present Address:

W. W. Hartup

North Carolina Cooperative Extension, 1450 Fairchild Rd., Winston-Salem, NC 27105, USA 


\section{Introduction}

Freshwater fishes are disproportionally imperiled relative to terrestrial vertebrates, and are experiencing rapid rates of extinction (Ricciardi and Rasmussen 1999; Burkhead 2012). Factors contributing to this are species-specific and usually synergistic, but most often involve habitat destruction or modification (Jelks et al. 2008). Migratory fishes, such as most salmonids, are especially vulnerable to habitat modification involving passage barriers, such as dams, and as a result are almost universally imperiled (Freeman et al. 2003).

Small species with shorter migration routes are no less imperiled than larger species with longer routes. All four of the migratory species of Ozarka are considered imperiled, including the federally listed, threatened Slackwater Darter (Etheostoma boschungi) (Jelks et al. 2008). Darters in the subgenus Ozarka are migratory at a smaller spatial scale than those fishes usually associated with spawning migrations, and are overlooked as examples of migratory species affected by passage barriers. The maximum size of Slackwater Darter is approximately $51 \mathrm{~mm}$, and it is thought to travel up to a kilometer from non-breeding streams to breeding sites in floodplain seepage areas (Boschung 1976). In the case of small fishes, culverts at road crossing can act as passage barriers (Warren and Pardew 1998), and agencies are focusing on culvert removal as part of conservation measures for many species, including Slackwater Darters.

In addition to passage barriers, a loss of connectivity between breeding and nonbreeding sites and destruction of seepage areas are considered detrimental to successful reproduction of this species (US Fish and Wildlife Service 1984). Specifically, channel incision, caused by hydrologic alterations, may produce bank heights (measured as bank height ratio) that prohibit flooding, and disconnect stream channels with the floodplain where seepage areas used for breeding are found. The effect of activities such as the removal of large woody debris, channelization and stream straightening are all known to cause altered hydrology and bank destabilization (Smith et al. 1993; Shields et al. 1994).

Slackwater Darters, like most species in the subgenus Ozarka, have distinct breeding and non-breeding habitats (Page 1983). Fish migrate from resident stream habitat in the winter, and move onto breeding sites around February, during periods of high rainfall typical of the winter months. Breeding habitat is characterized by areas of seepage water, either in small streams or in seasonally flooded fields (Boschung 1979; Boschung and Neiland 1986). Characteristic vegetation includes Juncus, where Slackwater Darter are known to attach eggs, and adults and juveniles migrate downstream to larger streams in early spring, where they are rarely collected (Boschung 1979; Boschung and Neiland 1986). In 1976, Boschung estimated, via mark/recapture, the population of Slackwater Darter in Cemetery Branch (Cypress Creek system) as 800-1,200 individuals. He also noted that bank heights in this stream were $30-45 \mathrm{~cm}$ above the stream channel, and emphasized the importance of connectivity of stream channels and floodplain seepage areas for successful migration to spawning areas.

Slackwater Darters are endemic to tributaries of the Tennessee River in Alabama and Tennessee. The species is historically known from headwaters of the Buffalo River and Shoal Creek, Tennessee; from Cypress Creek and Brier Fork systems, Alabama and Tennessee; and Limestone Creek and Swan Creek systems, Alabama (Fig. 1) (USFWS 1984, J Powell, USFWS, personal communication). Because the species aggregates in relatively small areas during the breeding season (Boschung 1979; Boschung and Neiland 1986), it is assumed that detectability during this time is higher at these locations than in non-breeding habitat outside of the spawning season. In a comprehensive survey conducted 1992-1994, Slackwater Darters were present at 22 sites (all presumed breeding sites) in 
these streams (146 new and historical sites sampled). Of the 21 historical sites surveyed (breeding and non-breeding sites), Slackwater Darter was found at only 10 (all breeding sites), a $45 \%$ reduction of the originally known range since the 1970s (McGregor and Shepard 1995).

The objectives of this study were to document the current distribution of Slackwater Darters relative to historical records and to discuss potential factors contributing to their decline. The current study included all known breeding sites, as well as potential nonbreeding sites.

\section{Methods}

The tributaries where Slackwater Darters are found lie primarily within the Highland Rim physiographic region in Alabama and Tennessee. With the exception of the Buffalo River populations, which flow into the Duck River, all populations are found in south-flowing tributaries of the Tennessee River (Wall and Williams 1974; McGregor and Shepard 1995).

Surveys for this study were conducted in 2001-02, 2007-08 and 2012-13. Historic sites were chosen based on the results of Wall and Williams (1974) Boschung $(1976,1979)$ and McGregor and Shepard (1995), and included all known breeding and non-breeding sites as well as potential, new breeding and non-breeding sites based on on-site habitat assessment and proximity to historic sites (56 total sites, 25 non-breeding 31 potential breeding sites). Breeding sites were sampled from January to early March; non-breeding sites were sampled from June to August. Sampling gear included $3.05 \mathrm{~m}$ seines and dipnets in seepage areas (breeding habitats), and a Smith Root backpack electrofisher and $3.05 \mathrm{~m}$ seine in streams (non-breeding sites). Sites were sampled from $30 \mathrm{~min}$. and for $75 \mathrm{~m}$ (all seepage areas) to $1.0-1.5 \mathrm{~h}$ and $150 \mathrm{~m}$ (non-breeding sites), depending on size and complexity of the habitat. Standard length (SL, mm) of each fish collected was measured, and photographs of representative specimens were taken. All fish were released.

Detectability (number of times species present/number of sampling trips) of Slackwater Darter was calculated for sites visited multiple times and where the species was collected. Data included samples from the 1970s (Wall and Williams 1974; Boschung 1976, 1979) a 1992-94 survey by McGregor and Shepard (1995) and data from the current study (2000s). Data on abundance over time at the Middle Cypress Creek site (25) was standardized for a $1 \mathrm{~h}$, three persons sampling effort.

At selected historical and current breeding localities, bank height ratio was measured as average height of both banks+bankfull water depth/bankfull water depth (http://water.epa. gov/scitech/datait/tools/warsss/pla_box07.cfm). Since historical data on bank height ratio is lacking, sites were selected as representatives of major tributaries within the range of the species that included sites with and without positive detection of Slackwater Darter.

\section{Results}

Sampling for Slackwater Darter during three time periods detected the species at a total of 10 of 56 sites (Appendix, Figs. 1, 2). Sixteen sites were sampled repeatedly (Table 1). Of these, only one site consistently sustains the species with $100 \%$ detectability, and is a breeding site (site 25, Figs. 1, 2). Of the 21 originally known sites, this is the only site where Slackwater Darter was detected, a $95 \%$ reduction of the originally known range. Of the 11 sites with positive detection in common with the 1992-1994 survey, Slackwater 


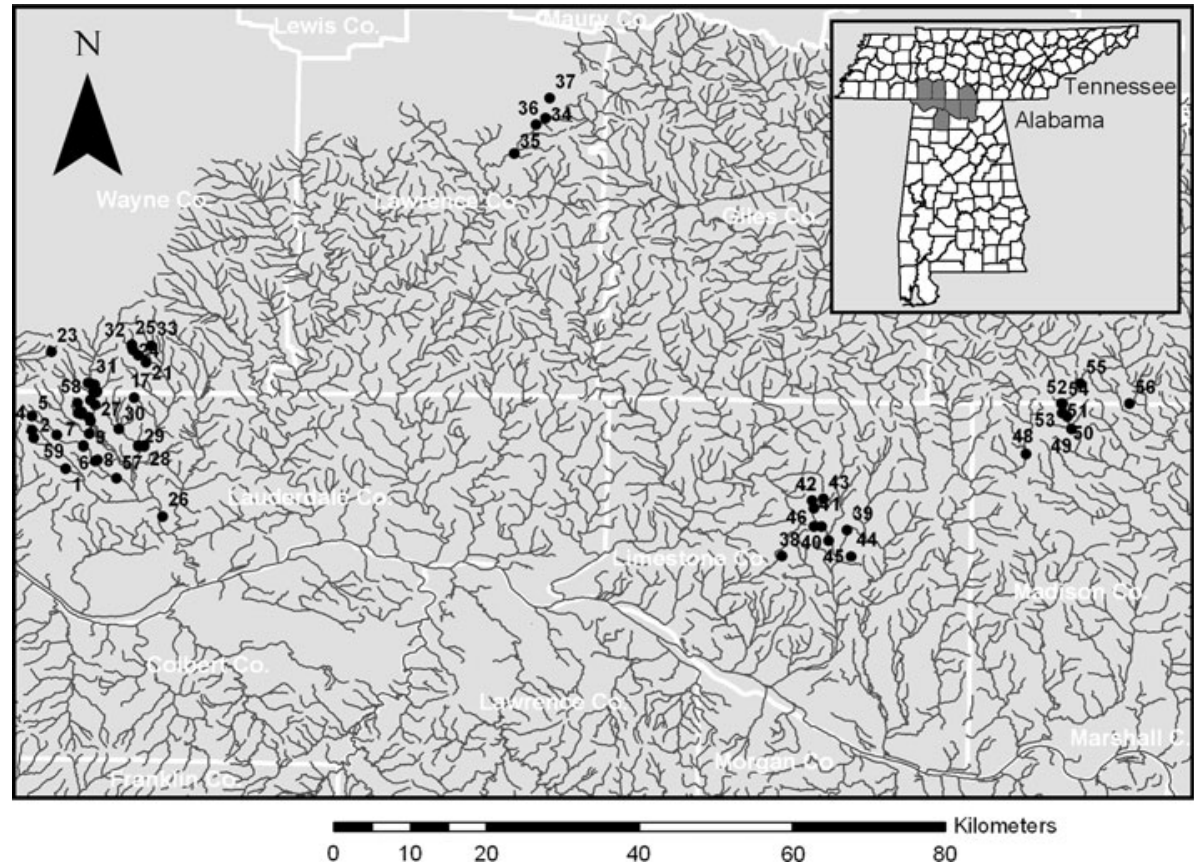

Fig. 1 Distributional range of Etheostoma boschungi, based on this study. Circles indicate positive detection in the current study; squares are historical sites where the species was not detected in the 2001-13 sampling period. Site numbers correspond to the Appendix

Darter was detected at five sites (all breeding sites), suggesting a $45 \%$ reduction in range, typically with a higher number of sampling trips (Table 1). Six of the ten sites with positive detection in this study were breeding sites, while four were samples taken in nonbreeding habitat outside of the spawning season (Appendix). Five of these ( 2 breeding and 3 non-breeding sites) were novel (e.g., not shared with previous studies).

Other sites that were shared with the previous survey have detectabilities ranging from 14 to $25 \%$ (Table 1). This contrasts with the survey conducted by McGregor and Shepard (1995), where detectability was $100 \%$. Slackwater Darters were not detected at other historical sites, however, the species was detected at three sites in the Brier Fork system that were not sampled by McGregor and Shepard (1995) (sites 49, 50 and 55; Fig. 1, Appendix), and one additional site in Middle Cypress Creek (site 32, Fig. 2, Appendix).

The most dramatic decline, in both distribution and numbers, is in the Cypress Creek system (Fig. 2). Sites with positive detection have decreased with each successive sampling period. Most notably, Slackwater Darter is now absent from the North Fork, Cypress Creek system. Although numbers of specimens are difficult to compare due to variable effort, studies from the 1970s reported 65 specimens from Lindsey Creek, while only 11 were collected in 1992-94; 10 were collected from Dulin Branch in the 1970s and 25 were collected in 1992-94; 19 were collected from Middle Cypress Creek and 53 were collected in 1992-94 (McGregor and Shepard 1995). Slackwater Darter was absent from other locations in 1992-94 and in the current study.

Repeated sampling of the Middle Cypress Creek site during the breeding season (January to early March) (site 25, Figs. 1,2) suggests a decline in numbers of Slackwater 
1970s

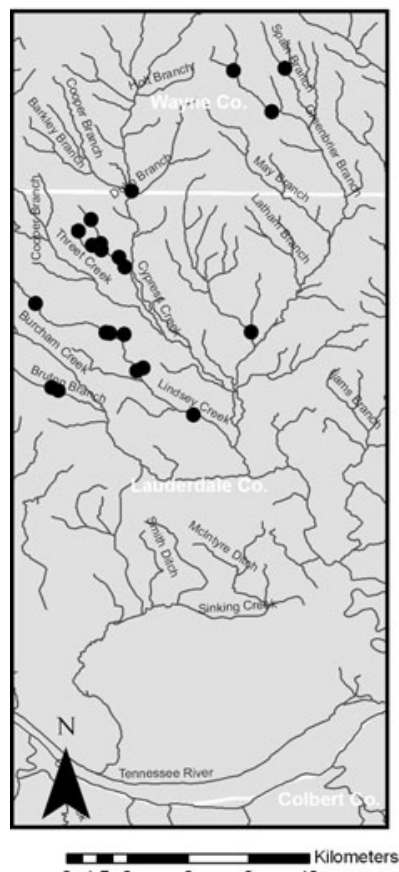

1990s

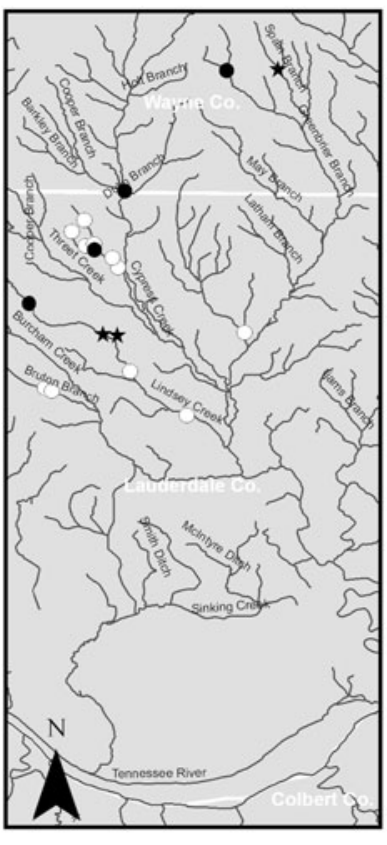

Present $\bigcirc$ Absent

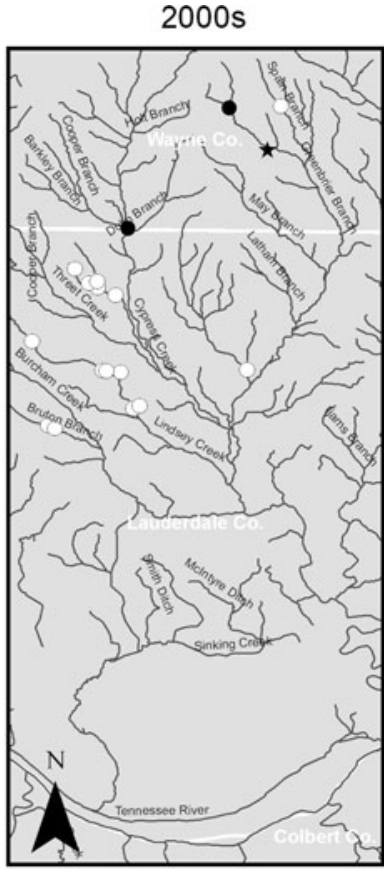

Present at new locality

Fig. 2 Sampling sites for Etheostoma boschungi in the Cypress Creek watershed over time. White circles are sites where the species was not detected; black circles were sites with positive detection, and stars represent new site records for that time period

Darter collected over time (Fig. 3). Average, effort-adjusted numbers were: 109 in 2001 ( $n=3$ samples), 40 in 2002 ( $n=2$ samples), 21 in $2006(n=2), 25$ in $2007(n=1), 6$ in $2012(n=1)$ and 5 in $2013(n=1)$. Collections made in the seepage area and adjacent stream at different times of the year (February, March, July and August) indicate that the darters reside in both areas throughout the year.

Data on bank height ratio (BHR), taken at selected historical breeding sites, suggests a relationship between a low ratio, indicating probable connection between the stream and the floodplain, and a high ratio, unlikely to maintain a connection to the floodplain during high water (Table 2). Sites with extant populations of Slackwater Darter had bank height ratios less than 2, while those where Slackwater Darter have not been recently detected had bank height ratios of 2.3-8.4. (mean BHR extant sites $=1.22, \mathrm{SD}=0.28$; mean $\mathrm{BHR}$ extirpated sites $=4.95, \mathrm{SD}=2.4 ; F=12.82, p=0.007, t$ test $)$.

\section{Discussion}

These results suggest at least a $45 \%$ historical range reduction of Slackwater Darter in approximately 15 years. In addition, the species had not been detected from a major portion of its range in the Cypress Creek system from the 1970 to the 1990s, and was not detected during this study. In terms of numbers, the species has declined from $100 \%$ 
Table 1 Detection of Etheostoma boschungi by repeated sampling of locations over time

\begin{tabular}{|c|c|c|c|}
\hline Stream and site \# & $1970 \mathrm{~s}$ & 1992-1994 & 2001-2013 \\
\hline \multicolumn{4}{|l|}{ Cypress Creek system } \\
\hline Lindsey, $57^{\mathrm{a}}$ & $100 \%$ & 0 & - \\
\hline Lindsey, $7^{\mathrm{a}}$ & $100 \%$ & 0 & $0 n=6$ \\
\hline Lindsey, $4^{\mathrm{a}}$ & $100 \%$ & 0 & $0 n=4$ \\
\hline Greenbrier, 29 & $100 \%$ & 0 & $0 n=3$ \\
\hline Middle Cypress, $28^{a}$ & $100 \%$ & 0 & 0 \\
\hline Burcham, 1 & $100 \%$ & 0 & 0 \\
\hline Bruton, 2 & $100 \%$ & 0 & 0 \\
\hline N Fork, 11 & $100 \%$ & 0 & $0 n=2$ \\
\hline N Fork, 13 & $100 \%$ & 0 & $0 n=2$ \\
\hline Cemetery Branch, 10 & $100 \%$ & 0 & 0 \\
\hline Middle Cypress, 25 & $100 \%$ & $100 \% n=3$ & $100 \% 10 / 10$ \\
\hline Middle Cypress, $32^{\mathrm{a}}$ & - & - & $100 \% 1 / 1$ \\
\hline Elijah Branch, 12 & $100 \%$ & 0 & 0 \\
\hline Spain Branch, $33^{\mathrm{a}}$ & - & $100 \%$ & 0 \\
\hline Lindsey, 5 & - & $100 \%$ & 0 \\
\hline Cypress Inn, 15 & $100 \%$ & $100 \% n=2$ & 0 \\
\hline Natchez Trace, 20 & - & $100 \% n=4$ & $25 \% 3 / 12$ \\
\hline \multicolumn{4}{|l|}{ Little Shoal Creek } \\
\hline Little Shoal, 34 & - & $100 \% n=3$ & $16 \% 1 / 6$ \\
\hline \multicolumn{4}{|l|}{ Swan Creek } \\
\hline Swan, $45^{\mathrm{a}}$ & - & $100 \% n=10$ & $20 \% 1 / 5$ \\
\hline Swan, 40 & - & $100 \% n=2$ & $0 n=7$ \\
\hline Collier Creek, 39 & - & $100 \%$ & $0 n=3$ \\
\hline \multicolumn{4}{|l|}{ Brier Fork } \\
\hline Brier Fork, 51 & - & $100 \% n=2$ & $16 \% 1 / 6$ \\
\hline Brier Fork, 52 & - & $100 \% n=5$ & $0 n=3$ \\
\hline Brier Fork, $49^{\mathrm{a}}$ & - & - & $33 \% 1 / 3$ \\
\hline Brier Fork, 54 & - & - & $100 \% 1 / 1$ \\
\hline Brier Fork, $50^{\mathrm{a}}$ & - & - & $50 \% 1 / 2$ \\
\hline Brier Fork, 55 & - & - & $100 \% 1 / 1$ \\
\hline Copeland Creek, 56 & $100 \%$ & $100 \%$ & $0 n=2$ \\
\hline West Fork ${ }^{\mathrm{b}}$ & $100 \%$ & 0 & - \\
\hline \multicolumn{4}{|l|}{ Buffalo River } \\
\hline Chief Creek, 37 & $100 \%$ & 0 & $0 n=2$ \\
\hline
\end{tabular}

Only sites with positive detection during one of the three time periods included. Collections based on single sampling effort unless numbers of trips indicated. Fractions indicate number of positive detections over total number of sampling trips. Collections from the 1970s from Wall and Williams (1974) and Boschung (1976, 1979); 1992-94 from McGregor and Shepard (1995), and 2001-13, current study. Site numbers correspond to the Appendix

a Non-breeding sites

b Not sampled in 2000 s 


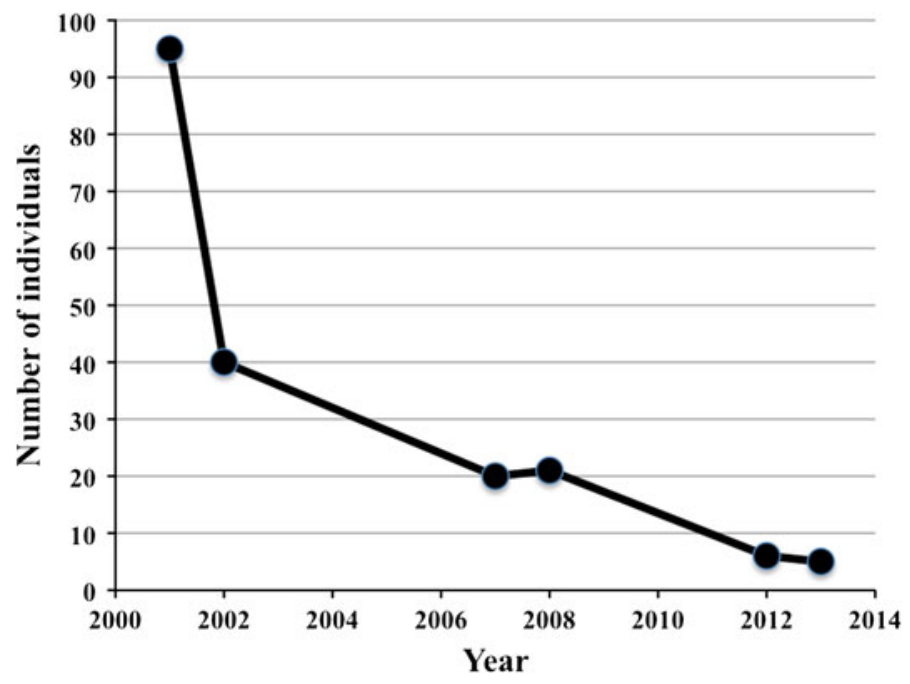

Fig. 3 Numbers of Etheostoma boschungi collected in Middle Cypress Creek (site 25) over time (2001-02, 2007-08, 2012-13), standardized for a $1 \mathrm{~h}$ effort

Table 2 Bank height ratios (BHR) measured in 2007 at selected historical and current sites of positive detection for Etheostoma boschungi, as a measure of current channel connectivity

Positive versus negative detection in 2000 s, $F=12.82$, $p=0.007, t$-test

a Seepage area converted to a farm pond post 1995

\begin{tabular}{lll}
\hline Site & BHR & Year last detected \\
\hline Lindsey, 4 & 6.0 & 1974 \\
Lindsey, 7 & 4.0 & 1979 \\
Natchez Trace, 20 & 1.0 & 2010 \\
N Fork, 11 & 8.4 & 1979 \\
Cemetery Branch, 10 & 2.3 & 1979 \\
Elijah Branch, 12 $_{\text {Middle Cypress, 25 }}$ & 6.6 & 1979 \\
Brier Fork, 50 & 1.3 & 2013 \\
Brier Fork, 51 & 2.4 & 1994 \\
Little Shoal, 34 & 1.0 & 2007 \\
\hline
\end{tabular}

detectability to $14-100 \%$ at all but one site sampled repeatedly. In addition, the species is less abundant at the one site with $100 \%$ detectability.

It is difficult to compare numbers of specimens collected with previous studies due to variable effort. However, in the 1970s, numbers as high as 83 were reported from one breeding site collection in the Cypress Creek system. Boschung (1976) estimated 800-1200 Slackwater Darter were present in one segment of Cemetery Branch in the Cypress Creek system, where they are now presumed extirpated. Recent surveys produce numbers of specimens comparable to this at only one site, in the Cypress Creek system, and evidence indicates a decline over time at this location. Since breeding sites are targeted for sampling, it is difficult to compare detectability of non-breeding and breeding sites over time. The species was detected at four of 25 non-breeding sites during this study, however. Non-breeding sites should be included in future monitoring efforts for these species, as the potential environmental stressors in these habitats are poorly known. 
Although two new breeding sites were discovered during this study, one of them is in an industrial cotton field, and it is doubtful that the seepage habitat will persist due to plowing. There are potential seepage areas in the headwaters of both the Brier Fork and Swan Creek systems, which should be explored and surveyed for Slackwater Darter during the breeding season.

The decline in distribution and abundance make detection of this species difficult to monitor. At many sites, numerous samples were necessary for the detection of Slackwater Darter, suggesting very low numbers of individuals are present relative to historical samples. Future monitoring must include multiple samples at each site to insure detection.

Several environmental problems may be contributing to the decline of this species, including various types of passage barriers, habitat degradation and the destruction of seepage areas via the construction of farm ponds. Boschung (1976) emphasized the importance of connectivity of breeding and non-breeding habitats, and gave a range of bank heights at existing breeding sites as 30-45 cm. Although it is impossible to go back and gather comparative data, data on current bank height ratios, low at extant and higher at apparently extirpated breeding sites and associated stream channels suggest that channel incision may play a role in the decline of this species at some sites. Additionally, culverts at road crossings are known passage barriers to small fishes (Boubee et al. 1999; Kemp and O'Hanlley 2010).

Future conservation efforts for this species should include an evaluation of potential environmental impacts on the migration of this species. Prioritization of breeding sites for protection is also essential for the persistence of Slackwater Darter.

Acknowledgments This project has been funded by Section 6 funds to the Alabama Department of Conservation and Natural Resources and was also supported by the US Fish and Wildlife Service. Thanks to Gabe Barrett, Ben Beck, Alice Best, Mary Katherine Bolling, Michelle Castro, Jenna Crovo, Brook Fluker, Jeff Garner, Chad Hartup, Steve Herrington, Dan Holt, Alexis Janosik, Andrew Jarret, Adam Kennon, Nicole Kierl, Kevin Kleiner, Abbey Kleiner, Sipsey Kleiner, Chris Matechik, Stuart McGregor, Nick Ozburn, Cathy Phillips, Bryan Phillips, Morgan Scarbough, Erica Williams, and Jeff Zeyl for help with field work.

Open Access This article is distributed under the terms of the Creative Commons Attribution License which permits any use, distribution, and reproduction in any medium, provided the original author(s) and the source are credited.

\section{Appendix: Sites sampled for Slackwater Darters during breeding and non-breeding seasons. Site numbers correspond to maps (Figs. 1, 2). Sites with * mark locations where Slackwater Darters were detected}

1. Burcham Branch, Natchez Trace Parkway, Lauderdale Co., AL, -87.8499 N, 34.91643 W 2/2/07

2. Bruton Branch, co rd. 158, Lauderdale Co., AL $-87.88706 \mathrm{~N}, 34.95141 \mathrm{~W}$

$1 / 25 / 13,2 / 2 / 07$

3. Lindsey Creek, Natchez Trace Parkway, Lauderdale Co., AL, $-87.8286 \mathrm{~N}, 34.94245 \mathrm{~W}$ 2/2/07, 7/26/07

4. Lindsey Creek, co. rd. 60, Lauderdale Co., AL, -87.8891N, 34.96104W 1/27/01, 3/2/01, 3/16/02, 3/10/07 
5. Lindsey Creek, Murphy's Chapel, Lauderdale Co., AL, -87.8891N, 34.97714W 3/2/01, 3/16/02, 3/10/07, 1/15/13

6. Lindsey Creek, co rd. 81 , Lauderdale Co., AL, $-87.81496 \mathrm{~N}, 34.92533 \mathrm{~W}$ 11/11/2000, 8/1/07, 8/4/08

7. Lindsey Creek, co. rd. 5

Lauderdale Co., AL, $-87.8347 \mathrm{~N}, 34.9812 \mathrm{~W}$

11/11/2000, 1/27/01, 3/10/01, 3/17/02, 8/4/08, 6/27/12, 1/15/13

8. Lindsey Creek, E Natchez Trace Parkway

Lauderdale Co., AL

$-87.8121 \mathrm{~N}, 34.9265 \mathrm{~W}$

$8 / 4 / 08$

9. Threet Creek at Natchez Trace, Lauderdale Co., AL

$-87.82156 \mathrm{~N}, 34.956233 \mathrm{~W}$

$3 / 9 / 02$

10. Cemetery Branch, Natchez Trace Parkway, Lauderdale Co., AL, -87.82034N, 34.97171W 3/30/02, 2/24/07

11. North Fork Cypress Creek, Natchez Trace Parkway, Lauderdale Co., AL, $-87.82275 \mathrm{~N}, 34.9759 \mathrm{~W}$ 3/10/01, 3/11/07

12. Elijah Branch, co rd. 85/co rd. 5, Lauderdale Co., AL, -87.83064N, 34.97938W 2/24/07

13. North Fork Cypress Creek, co rd. 85/co rd. 5, Lauderdale Co., AL, $-87.831 \mathrm{~N}, 34.98215 \mathrm{~W}$ 3/10/01, 2/24/07

14. Trib., Cypress Creek, Natchez Trace Parkway, Lauderdale Co., AL, -87.82067N, 34.99599W 3/11/07

15. Cypress Creek, 0.5 mi SW Cypress Inn, Wayne Co., TN, $-87.81713 \mathrm{~N}, 35.00563 \mathrm{~W}$ 3/10/7, 8/4/08

16. Dulin Branch, at Hwy 157, Lauderdale Co., AL, $-87.813611 \mathrm{~N}, 35.00527 \mathrm{~W}$ 3/30/02, 1/26/13

17. Lathum Branch, Lauderdale Co., AL $-87.76890 \mathrm{~N}, 34.99924 \mathrm{~W}$ $1 / 26 / 13$

18. Trib., Dulin Branch, N Hwy 227, Wayne Co., TN $-87.81555 \mathrm{~N}, 35.014444 \mathrm{~W}$ $3 / 16 / 02$

19. Cypress Creek, Natchez Trace Parkway, AL/TN state line, $-87.81245 \mathrm{~N}, 35.00652 \mathrm{~W}$ 3/11/07, 8/4/08, 6/27/12

*20. Trib., Cypress Creek, Natchez Trace Parkway, Wayne Co., TN, -87.82314N, 35.0160W 
1 Slackwater Darter collected, 3/10/07

1 Slackwater Darter collected, 2/27/08

2 Slackwater Darters collected, $1 / 18 / 10$

3/2/01, 3/10/01, 3/9/02, 3/16/02, 3/30/02, 3/11/07, 8/4/08, 1/25/13, 2/7/13

21. Trib., Middle Cypress Creek at power line, Pigg rd.,

Wayne Co., TN, -87.75489N, 35.04084W

$2 / 2 / 07$

22. Trib., Middle Cypress Creek, E Gilchrest rd. and Pigg rd.,

Wayne Co., TN, $-87.76449 \mathrm{~N}, 35.04931 \mathrm{~W}$

3/11/07

23. Trib., Middle Cypress Creek, Dodd rd. and Gilchrest rd.,

Wayne Co., TN, $-87.86627 \mathrm{~N}, 35.05294 \mathrm{~W}$

3/11/07, 8/4/08

24. Trib., Middle Cypress Creek, Dodd rd., Wayne Co., TN, $-87.77062 \mathrm{~N}, 35.0555 \mathrm{~W}$ 3/10/07

*25. Trib., Middle Cypress Creek,

Wayne Co., TN, -87.77153N, 35.06171W

133 Slackwater Darters collected, 3/3/01

141 Slackwater Darters collected, 3/10/01

41 Slackwater Darters collected, 3/13/01

37 Slackwater Darters collected, 3/9/02

42 Slackwater Darters collected, 3/16/02

20 Slackwater Darters collected, 2/2/07

17 Slackwater Darters collected, 2/28/08

25 Slackwater Darters collected, 8/5/08

6 Slackwater Darters collected, 7/11/12

5 Slackwater Darters collected, 1/25/13

26. Cypress Creek, co rd. 16,

Lauderdale Co., AL, $-87.73547 \mathrm{~N}, 34.86030 \mathrm{~W}$

8/1/07, 8/4/08

27. Cypress Creek, co rd. 10, Lauderdale co., AL

$-87.814652 \mathrm{~N}, 34.990676 \mathrm{~W}$

$6 / 27 / 12$

28. Middle Cypress Creek, co rd. 8,

Lauderdale Co., AL, -87.75691N, 34.94247W

$8 / 1 / 07$

29. Greenbrier Branch, co rd. 8,

Lauderdale Co., AL, $-87.76386 \mathrm{~N}, 34.942530 \mathrm{~W}$

3/17/02, 8/1/07

30. Greenbrier Branch at co rd. 10

Lauderdale Co., AL, -87.79357N, 34.59002W $1 / 26 / 13$

31. Trib., Cypress Creek, Natchez Trace Parkway, Wayne Co., TN, $-87.8207 \mathrm{~N}, 35.0158 \mathrm{~W}$ $8 / 4 / 08$

*32. Trib., Middle Cypress Creek, Dodd rd., Wayne Co., TN, $-87.772 \mathrm{~N}, 35.0592 \mathrm{~W}$

1 Slackwater Darter collected, 8/4/08 
33. Spain Branch, Gilchrest rd., Wayne Co., TN $-87.74900 \mathrm{~N}, 35.06041 \mathrm{~W}$ $1 / 26 / 13$

*34. Little Shoal Creek, Dooley rd., Lawrence Co., TN, $-87.28507 \mathrm{~N}, 35.32787 \mathrm{~W}$

5 E. boschungi, 3/9/02

2/2/07, 8/1/07. 2/28/08, 8/5/08, 7/10/12

35. Little Shoal Creek, Beasley rd.,

Lawrence Co., TN, $-87.32202 \mathrm{~N}, 35.28657 \mathrm{~W}$

8/1/07, 8/5/08

36. Little Shoal Creek at Hwy 43, Lawerence Co., TN

$-87.296021 \mathrm{~N}, 35.32 .0327 \mathrm{~W}$

$7 / 10 / 12$

37. Chief Creek at Hwy 240, Lawrence Co., TN

$-87.425400 \mathrm{~N}, 35.372783 \mathrm{~W}$

3/9/02, $1 / 26 / 13$

38. Round Island Creek, $2.0 \mathrm{mi} \mathrm{N}$ Athens,

Limestone Co., AL, -87.00705N, 34.81326W

2/23/07

39. Collier Branch, Bean rd. just E I65,

Limestone Co., AL, $-86.93085 \mathrm{~N}, 34.84381 \mathrm{~W}$

2/23/07, 3/27/08, 2/8/13

40. Swan Creek, Piney Chapel rd.,

Limestone Co., AL, -86.96057N, 34.84842NW

1/26/01, 3/4/01, 3/17/02, 2/23/07, 8/2/07, 8/6/08, 7/10/12

41. Swan Creek, Huber rd.,

Limestone Co., AL, -86.9697N, 34.86986W

2/23/07, 8/5/08, 7/10/12, 2/8/13

42. Roadside ditch (Swan Creek drainage), co rd. 55,

Limestone Co., AL, $-86.97186 \mathrm{~N}, 34.8786 \mathrm{~W}$

2/23/07

43. Roadside seep (Swan Creek drainage), co rd. 80,

Limestone Co., AL, $-86.95825 \mathrm{~N}, 34.88084 \mathrm{~W}$

2/23/07

44. Trib., Swan Creek at Linton drive

Limestone Co., AL

$-86.92570 \mathrm{~N}, 34.8130 \mathrm{~W}$

$2 / 8 / 13$

*45. Swan Creek, Elkton rd.,

Limestone Co., AL, -86.95181N, 34.83174W

2 Slackwater Darters collected, 8/6/08

1/26/01, 8/2/07, 7/10/12, 2/8/13

46. Roadside seep (Swan Creek drainage), co. rd. 55,

Limestone Co., AL, -86.9697N, 34.8484W

3/27/08

47. Piney Creek at Johnson rd.

Limestone Co., AL

$-86.32080 \mathrm{~N}, 34.84009 \mathrm{~W}$

$2 / 8 / 13$ 
48. Limestone Creek at Ready Section rd.

Madison Co., AL, -86.71910N, 34.9339W

7/10/12

*49. Brier Fork, Bobo Section rd.,

Madison Co., AL, -86.6658N, 34.9623W

19 Slackwater Darters collected, 8/2/07

7/10/12, 8/7/08

*50. Trib., Brier Fork, Elkwood Section rd.,

Madison Co., AL, $-86.6707 \mathrm{~N}, 34.9765 \mathrm{~W}$

5 Slackwater Darters collected, 8/7/08

8/1/07

*51. Trib., Brier Fork, Scott rd. State line rd.,

Lincoln Co., TN, -86.6780N, 34.9917W

3 Slackwater Darters collected, 3/9/07

3/17/02, 8/2/07, 2/28/08, 8/7/08, 2/9/13

52. Brier Fork, Scott orchard,

Madison Co., AL, -86.6779N, 34.9919W

3/30/02, 3/10/07. 8/6/08

53. Trib., Brier Fork, Scott rd.

Lincoln Co., TN, $-86.6770 \mathrm{~N}, 34.9811 \mathrm{~W}$

$8 / 6 / 08$

*54. Trib., Brier Fork, Scott Orchard rd.,

Lincoln Co., TN, $-86.6767 \mathrm{~N}, 34.9917 \mathrm{~W}$

5 Slackwater Darters collected, 2/29/08

*55. Brier Fork, Fowler rd.,

Lincoln Co., TN, $-86.6553 \mathrm{~N}, 35.0154 \mathrm{~W}$

3 Slackwater Darters collected, 2/29/08

56. Copeland Creek, Charity Lane, Madison Co., AL

$-86.59776 \mathrm{~N}, 34.99167 \mathrm{~W}$

8/2/07, 2/9/13

57. Lindsey Creek, co rd. 15,

Lauderdale Co., AL $-87.7898 \mathrm{~N}, 34.9055 \mathrm{~W}$

$8 / 4 / 08$

58. North Fork, Cypress Creek, co rd. 10

Lauderdale Co., AL -87.8354N, 34.9927W

2/24/07

59. Lindsey Creek

Lauderdale Co., AL -87.8600N, 34.9554W

2/2/07

\section{References}

Boschung HT (1976) 1. An evaluation of the Slackwater Darter Etheostoma boschungi, relative to its range, critical habitat, and reproductive habits in the Cypress Creek watershed and adjacent stream systems. 2. An assessment of the probable impacts of the Cypress Creek watershed project on the Slackwater Darter and its critical habitat. Report to Soil Conservation Service, p 51

Boschung HT (1979) Report on the breeding habits of the Slackwater Darter (Percidae: Etheostoma boschungi) in the Cypress Creek watershed. Report to US Department of Agriculture, Soil Conservation Service, Auburn, AL p 26 
Boschung HT, Neiland D (1986) Biology and conservation of the Slackwater Darter, Etheostoma boschungi (Pisces: Percidae). Southeast Fish Counc Proc 4:1-4

Boubee J, Jowett I, Nichols S, Williams E (1999) Fish passage at culverts: a review, with possible solutions for New Zealand indigenous species. Report to Department of Conservation, Wellington, New Zealand

Burkhead N (2012) Extinction rates in North American freshwater fishes, 1900-2010. Bioscience 62:798-808

Freeman MC, Pringle CM, Greathouse EA, Freeman BJ (2003) Ecosystem-level consequences of migratory faunal depletion caused by dams. Am Fish Soc Symp 35:255-266

Jelks HL, Walsh SJ, Burkhead NM, Contreras-Balderas S, Diaz-Pardo E, Hendrickson DA, Lyons J, Mandrak NE, McCormick F, Nelson JS, Platania SP, Porter BA, Renaud CB, Schmitter-Soto JJ, Taylor EB, Warren ML Jr (2008) Conservation status of imperiled North American freshwater and diadromous fishes. Fisheries 33:373-407

Kemp PS, O'Hanley JR (2010) Procedures for evaluating and prioritizing the removal of fish passage barriers: a synthesis. Fish Manag Ecol 17:297-322

McGregor SW, Shepard TE (1995) Investigations of Slackwater Darter, Etheostoma boschungi, populations, 1992-94. Geological survey of Alabama Circular, vol 184, p 33

Page LM (1983) Handbook of darters. T.F.H Publications, Neptune City

Ricciardi A, Rasmussen JB (1999) Extinction rates of North American freshwater fauna. Conserv Biol $13: 1220-1222$

Shields FD, Knight SS, Cooper CM (1994) Effects of channel incision on base flow stream habitats and fishes. Environ Manag 18:43-57

Smith RD, Side RC, Porter PE, Noel JR (1993) Effects of experimental removal of woody debris on the channel morphology of a forest, gravel-bed stream. J Hydrol 152:153-178

US Fish and Wildlife Service (1984) Slackwater Darter recovery plan. USFWS, Atlanta, p 45

Wall BR, Williams JD (1974) Etheostoma boschungi, a new percid fish from the Tennessee River drainage in Northern Alabama and Western Tennessee. Tulane Stud Zool Bot 18:172-182

Warren ML, Pardew MG (1998) Road crossings as barriers to small-stream fish movement. Trans Am Fish Soc 127:637-644 